\title{
Response of Rapes (Brassica napus L.) to Nano- Iron Fertilization under semi-arid Region conditions
}

Lamiaa A. Mutlag ${ }^{1}$, Nagam A. Meshaimsh ${ }^{1}$, Hasan H. Mahdi ${ }^{1}$, Raghad S. Mouhamad ${ }^{1 *}$, Hasan H. Khamatt ${ }^{1}$, Obeyed H. Jasaam ${ }^{1}$, Saham M. Bajy ${ }^{1}$

DOI. 10.21931/RB/2019.04.01.3

\begin{abstract}
The field experiment was conducted in the season of 2017-2018 at the Agricultural Research Department-AL-Azafrinih/Baghdad-Iraq. This study aimed to determine the effect of adding the Foliar Fe fertilization (Nano-Fe) and ground fertilization of $(\mathrm{N}, \mathrm{P})$ in the growth and production yield of rapes (Brassica napus L.). The experiment included three levels of foliar fertilization (Nano-Fe) that is $(0,5,10 \mathrm{Kg}$. ha-1) and one level of ground fertilization ( $100 \mathrm{Kg}$. ha-1, $\mathrm{P} 250 \mathrm{Kg}$. ha-1). The experiment designed according to Randomized Complete Block Design (R.C.B.D) with three replications each parameter. The studied traits were nutrients content (macro-micro) in seeds and soil, the percentage of protein, oil, and carbohydrate. All data were analyzed and used statistically. Results showed a significant difference between Nano-Fe fertilization and nutrient content ( N, Mn, K, Ca, Mg, S, and $\mathrm{Cu}$ ), $\mathrm{pH}$ in soil at the level of $10 \mathrm{~kg}$. ha-1, compared to no-fertilization. Moreover, the significant difference between Nano-Fe fertilization, yield (1425.6 kg. ha-1), the percentage of oil (52.16\%), protein content in seeds (46.5\%), carbohydrate (26.8\%), Nutrient content $\mathrm{N}$ and $\mathrm{P}$ in seeds at the level of $10 \mathrm{~kg}^{\text {. ha-1 }}$, compared to no-fertilization and the nutrient content $(\mathrm{Ca}, \mathrm{Mg}, \mathrm{Fe})$ in seeds at levelof5 kg. ha-1 ${ }^{-1}$ compared to no-fertilization. Current results suggested that Nano-Fe fertilization at the level of $10 \mathrm{~kg}$. ha-1 can be adopted as the best level for rapes (Brassica napus L.) cultivation under semi-arid conditions.
\end{abstract}

Keywords: Nano-iron fertilizer; yield; nutrients; protein.

\section{Introduction}

Brassica napus L. classifies to the Brassicaceae family and has become one of the important oilseed crops in the agricultural systems of semi-arid regions where water deficit and high temperatures restrict growth and yield during the reproductive growth in Iraq. Canola seeds contain $\geq 49 \%$ oil contents. Oil in rapeseed is often determined by fertilization of the plants ${ }^{7}$. For winter type canola growth, $50-100 \mathrm{~kg}$. ha-1fertilizer containing nitrogen with potassium and about 20 - $40 \mathrm{~kg}$. ha-1 calcium with phosphorus should be applied before or during planting ${ }^{8}$. In severe winters conditions, a substantial proportion of the canola leaves are killed by frost and is lost from the plant ${ }^{12}$. The decrease in yield oil content may be due to a deficiency of Fe that controls the metabolic transformations in the plants, so the quality of grain is determined by oil and protein seed content ${ }^{26}$.

According to the limitations of soil usage of micro-nutrients consolidation and residual effects, the foliar spraying or leaf feeding is one of the effective ways to resolve plants food requirement to micronutrients ${ }^{25}$. High phosphorus in the soil, high $\mathrm{pH}$, high lime, high soil moisture, are the causes of Fe deficiency in the soil ${ }^{21}$. If adequate and absorbable amounts of Fe are not available for the plant chlorophyll production in leaf decreases and the leaves become pale. It should be noted that not only Fe deficiency results in yellowish leaf, but also in some cases deficiency of nitrogen and some other nutrients, some pests, diseases, and low light lead to pale leaf ${ }^{22}$. Nano fertilizers are the most important function of nanotechnology in the production phase of agriculture.

Application of Nano fertilizers instead of conventional fertilizers, nutrients are provided to plants gradually. The na- notechnology increases the application efficiency of fertilizers, reduces soil pollution and environmental risks of chemical fertilizers ${ }^{11}$. Nanomaterials are much smaller and lighter; they interact better in the environment and may be a solution to the problem of iron nutrition in saline and lime soils. Iron Nano oxide is smaller than the conventional iron oxides and forms more complexes and makes the Fe more available to plants ${ }^{10} \mathrm{Fe}$ deficiency is a widespread nutritional problem in plants growing mainly in high $\mathrm{pH}$ and calcareous soils. Foliar application of Fe compounds with the technology of Nano may be a solution to the problem ${ }^{1}$. Iraq with arid and semi-arid climates always is faced with water shortages. Therefore, this study aimed to investigate the effect of Fe-foliar of Nano-iron on yield and yield components, soil minerals of $B$. napus.

\section{Materials and methods}

Field experiments were carried out at the Agricultural Research Department-AL-Azafrinih/Baghdad-Iraq in the season of 2017-2018. This study aimed to determine the effect of adding the Foliar Fe fertilization (Nano-Fe) and ground fertilization of (N, P) on the growth and production yield of rapes (Brassica napus L.). The soil was plowed, rotivated and leveled. The experiment divided to 3 blocks designed according to Randomized Complete Block Design (R.C.B.D) with three replications each parameter. Blocks were divided into 6 plots with an area of $(1 \times 2) \mathrm{m}^{2}$, and the plots were separated by 0.5 $m$ in width from all sides to avoid the effect of fertilization. Soil properties of the application areas shown in Table 1.

Treatments included the application of $\mathrm{N}$ and $\mathrm{P}$ in 100, 250 kg. ha-1 respectively. Another plot in each block has not been fertilized. Nano-Fe was added as Foliar fertilizer with le- 
vels of $0,5,10 \mathrm{~kg}$. ha-1. Rap was planted in rows aside plot with distance of $30 \mathrm{~cm}$ between each rows. Soil was irrigated after depletion of $40 \%$ of F.C. using gravimetric method.

Plants were harvested after maturity; soil samples were collected at the depth of 0-30 cm and ground. Samples of a plant were oven dried at $65^{\circ} \mathrm{C}$. The powder was digested using according to (Page, 1982). The contents of the mineral elements for $\mathrm{Ca}, \mathrm{Na}, \mathrm{Mg}, \mathrm{Mn}, \mathrm{K}, \mathrm{Zn}, \mathrm{Cu}$, and Fein soil determined using the DTPA method and analyzed by Atomic Absorption Spectroscopy (AAS). Electrical conductivity values were determined by EC meter in 1: 1soil water mixture (WTW, Page, 1982). $\mathrm{pH}$ was determined by a glass electrode $\mathrm{pH}$ meter calibrated with a standard solution in a 1: 1 soil-water mixture (Mclean, 1982). Available phosphorus (P) determined by the ascorbic acid method of $882 \mathrm{~nm}$ in a spectrophotometer (OLsen 1982). N percentage determined by the Kjeldahl method. Organic matter (OM) determined by Wakley - Black method (Nelson and Sommers, 1982). Soil texture determined by reading the hydrometer in water mixture for 40 seconds and 2 hours (Gee and Bauder, 1986). The contents of the mineral elements for $\mathrm{Ca}, \mathrm{Na}, \mathrm{Mg}, \mathrm{Mn}, \mathrm{K}, \mathrm{Zn}, \mathrm{Cu}$ and $\mathrm{Fe}$ in the plant determined using the digestion method and analyzed by Atomic Absorption Spectroscopy (AAS). The oil ratio, ash, carbohydrate, fiber and Humidity determined by the method of the Association of Official Analytical Chemists (AOAC) (5). Total protein content was determined by the Kjeldahl method (a nitrogen conversion factor of 5.95), methods described by Page (1982). Statistical analysis was done and Means have compared at Least significant differences (L.S.D). SAS and EXCEL software have been used.

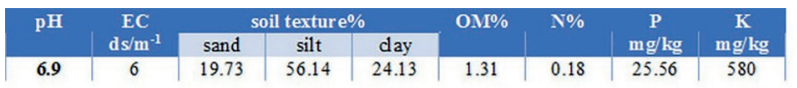

Table 1. Soil properties of the area under study.

\section{Results and discussion}

Table 2 showed significant increase of $\mathrm{N}$ content in the seeds, which were 31.6 - $33.7 \mathrm{mg} \mathrm{kg}^{-1}$, and decrease in $P$ content which were $7.5-6.1 \mathrm{mg} \mathrm{kg}^{-1}$ atlevel $(10 \mathrm{~kg}$. ha-1) Na-
no-Fe fertilization, compared to no-fertilization. For level (5 $\mathrm{kg}$. ha-1) Nano-Fe fertilization, shows significant increase in the $\mathrm{Ca}$ and $\mathrm{Mg}$ content in the seeds which were 7.3 - 8.1 $\mathrm{mg} \mathrm{kg}^{-1}, 3.2-3.5 \mathrm{mg} \mathrm{kg}^{-1}$ respectively, and the decrease in Fe content which were $94.1-85.2 \mathrm{mg} \mathrm{kg}^{-1}$ content, compared to no-fertilization. Increased nutrient content in seeds can be explained, because of addition Foliar Fe fertilization ( $\mathrm{Na}-$ no-Fe) and ground fertilizers (N, P). Iron is a critical element in cell metabolism, and it is contributory in photosynthesis, respiration, enzymes activity, chlorophyll production. ${ }^{15} \mathrm{Ni}-$ trogen is an essential nutrient for the synthesis of fat, which requires both $\mathrm{N}$ and carbon during seed development ${ }^{14}$. On the other hand, nitrogen plays the most critical role in building the protein structure ${ }^{6} . P$ is an integral component of several essential compounds in plant cells, including the sugar-phosphates contributory in respiration, photosynthesis and the phospholipids of plant membranes, the nucleotides used in plant energy metabolism and in molecules of DNA and RNA ${ }^{23}$. Calcium $(\mathrm{Ca})$ is essential in cell nucleus matrix. It activates enzymes, particularly those that are membrane-bound. It is thought that $\mathrm{Ca}$ is vital in the formation of cell membranes and lipid structures ${ }^{18}$.

Values marked with the same letter no significant difference at $p \leq 0.05$

The Data of Table 3 showed significant increasing of $\mathrm{N}$, $\mathrm{K}, \mathrm{Ca}, \mathrm{Mg}, \mathrm{S}, \mathrm{Mn}$ and $\mathrm{Cu}$ content in the soil which were 0.14$0.16 \mathrm{mg} \mathrm{kg}^{-1}, 125-158 \mathrm{mg} \mathrm{kg}^{-1}, 1200.3$ - $1375.2 \mathrm{mg} \mathrm{kg}^{-1}, 1260$ $1358 \mathrm{mg} \mathrm{kg}^{-1}, 340-420 \mathrm{mg} \mathrm{kg}^{-1}, 3.1-3.5 \mathrm{mg} \mathrm{kg}^{-1}, 52.1-55.2 \mathrm{mg}$ $\mathrm{kg}^{-1}, 0.86-1.3 \mathrm{mg} \mathrm{kg}^{-1}$ respectivelyand decrease in $\mathrm{pH}$ from 6.91 to6.36, at level $\left(10 \mathrm{~kg}\right.$ ha $\left.^{-1}\right)$ Nano-Fe fertilization, compared to no-fertilization. For level (5 kg. ha-1) Nano-Fe fertilization, showed significant increasing of $\mathrm{K}, \mathrm{Ca}, \mathrm{Mg}$, Fe, Cu content in the soil which were 128- 135 $\mathrm{mg} \mathrm{kg}^{-1}, 1257-1397 \mathrm{mg} \mathrm{kg}^{-1}, 320$ $399 \mathrm{mg} \mathrm{kg}^{-1}, 0.97$ - $1.2 \mathrm{mg} \mathrm{kg}^{-1}, 0.88$ - $1.17 \mathrm{mg} \mathrm{kg}^{-1}$ respectively, and decrease in pHfrom6.90to6.71, compared to no-fertilization. The increase in the concentration of nutrients in the soil can be explained, because of decrease the pH 6.91 - 6.36, when an addition of fertilizers and the soil texture of the application areas was silt clay loam. Management of plant nutrition is important to prevent reactions in reducing nutrient availability in the soil. Soil pH regulates the capacity of soils to store and

\begin{tabular}{|c|c|c|c|c|c|}
\hline \multirow[t]{4}{*}{ Parameter } & \multicolumn{5}{|c|}{ Foliar Fe fertilization } \\
\hline & \multicolumn{2}{|c|}{$0 \mathrm{~kg} \cdot \mathrm{ha}^{-1}$} & \multicolumn{2}{|c|}{$5 \mathrm{~kg} \cdot \mathrm{ha}^{-1}$} & $10 \mathrm{~kg}$. \\
\hline & \multicolumn{5}{|c|}{ ground fertilizer (N $100 \mathrm{~kg} \cdot \mathrm{ha}^{-1}$, P $\left.250 \mathrm{~kg} \cdot \mathrm{ha}^{-1}\right)$} \\
\hline & $\begin{array}{c}\text { No-Fer } \\
\left(\mathrm{kg} \cdot \mathrm{ha}^{-1}\right)\end{array}$ & Fer. $\left(\mathrm{kg} \cdot \mathrm{ha}^{-1}\right)$ & No-Fer. $\left(\mathrm{kg} \cdot \mathrm{ha}^{-1}\right)$ & Fer $\left(\mathrm{kg} \cdot \mathrm{ha}^{-1}\right)$ & No-Fer. $\left(\mathrm{kg} \cdot \mathrm{ha}^{-1}\right)$ \\
\hline & \multicolumn{5}{|c|}{ macro-micro nutrients of seeds $\left(\mathrm{mg} \mathrm{kg}^{-1}\right)$} \\
\hline $\mathbf{N}$ & $24.1^{3}$ & $27.1^{3}$ & $33.4^{b}$ & $33.9^{6}$ & $31.6^{c}$ \\
\hline $\mathbf{K}$ & $74.9^{3}$ & $69.1^{\circ}$ & $84.5^{c}$ & $80.2^{c}$ & $85.2^{c}$ \\
\hline Na & $2.2^{3}$ & $2.4^{3}$ & $2.7^{\circ}$ & $1.7^{6}$ & $1.8^{\mathrm{c}}$ \\
\hline $\mathrm{Ca}$ & $4.8^{3}$ & $5.8^{b}$ & $7.3^{c}$ & $8.1^{\mathrm{d}}$ & $7.9^{d}$ \\
\hline Mg & $2.9^{3}$ & $3.00^{3}$ & $3.2^{b}$ & $3.5^{6}$ & $3.6^{6}$ \\
\hline $\mathbf{P}$ & $5.3^{3}$ & $5.6^{3}$ & $5.8^{b}$ & $6.3^{b}$ & $7.5^{\mathrm{d}}$ \\
\hline $\mathbf{S}$ & 2.8 & 2.8 & 2.9 & 3 & $3.1^{3}$ \\
\hline $\mathrm{Fe}$ & $74.9^{3}$ & $79.8^{3}$ & $94.1^{b}$ & $85.2^{c}$ & $89.1^{d}$ \\
\hline Mn & 31.6 & 30.7 & 59.2 & 58.1 & 52.1 \\
\hline $\mathrm{Cu}$ & 2.7 & 2.8 & 3 & 2.3 & 2.4 \\
\hline
\end{tabular}

Table 2: The effect of foliar Nano- Fe fertilization and ground fertilizer ( $100 \mathrm{~kg}^{\text {. ha-1 }}$, P $250 \mathrm{~kg}$. ha-1) on the nutrient content of seed of winter rape in AL-Azafrinih station (2017-2018) 
supply nutrients, and thus contributes substantially to controlling productivity ${ }^{4}$.

Table 4 shows significant increase in the seed yield from 1298.6 to $1425.6 \mathrm{~kg} \mathrm{ha}^{-1}$ at level $\left(10 \mathrm{~kg} . \mathrm{ha}^{-1}\right)$ Nano-Fe fertilization, compared to no-fertilization. This may be due to increasing the number of capsules in the plant and the number of seeds in capsules. Recent research has shown that a small number of nutrients, especially $\mathrm{Zn}, \mathrm{Fe}$, and $\mathrm{Mn}$ applied by foliar spraying increases the yield of crops ${ }^{19}$ significantly. Keikha et al. ${ }^{9}$ found in studied the effect of Fe foliar application at the beginning of the flowering stage on canola and observed that the treatment increased grain yield from 4136 to $4557 \mathrm{~kg}$. ha 1. The status of seed yield is the most important field scale giving the final evaluation of agricultural operations to produce new recommendations on production.

Values marked with the same letter no significant difference at $p \leq 0.05$

The results showed a significant increase in the percentage of oil $52.16 \%$ at level (10 kg. ha-1) Nano-Fe Fertilization, compared to no-fertilization (Table 4). This may be due to increase in leaves area and surface area of capsules that were involved in the process of carbon representation and then increase the accumulation of dry matter and this has reflected positively on the percentage of oil in the seeds. The quality of rapeseed grain is determined by its oil and protein content ${ }^{17}$ Bahrani, A., ${ }^{2}$ showed oil percent and oil yield, NPK fertilizer and foliar application of $\mathrm{Fe}, \mathrm{Zn}$ and $\mathrm{Mn}$ treatments were significant in oil percent.

Chemical components, including protein, are essential traits to be taken into account in the study of rapes (Brassica napus $L$.). In results show increase percentage of seed protein $46.5 \%$ at level $\left(10 \mathrm{~kg} . \mathrm{ha}^{-1}\right)$ Nano-Fe fertilization, compared to no-fertilization (Table 4). This may be due to the inverse relationship between the percentage of oil and protein, increasing the percentage of oil in the seeds leads to decrease the percentage of protein, and conversely, this is similar with (24).

The other results: percentage of carbohydrate, Ash, Fiber and Humidity which were 26.8\%, 5.56\%,7.49 \%, 9.2\%, respectively found at level Nano-Fe fertilization $(10 \mathrm{~kg}$. ha-1), compared to no-fertilization (Table 4). In addition to oil production, rapeseed leaves and stems provide high-quality feed because of their low fiber content and high protein content and can be ground in animal feeds ${ }^{3}$.

Values marked with the same letter no significant difference at $p \leq 0.05$

Table 4: The effect of foliar Fe fertilization and ground fertilizer (N 100

\begin{tabular}{|ccc|}
\hline Peak & Title $(\mathrm{vg} / \mathrm{mL})$ & $\mathbf{2 6 0 / 2 8 0}$ ratio \\
\hline 1 & $10^{5}$ & 0.601 \\
\hline 2 & $10^{8}$ & 1.334 \\
\hline
\end{tabular}

$\mathrm{kg} \cdot \mathrm{ha}^{-1}, \mathrm{P} 250 \mathrm{~kg} \cdot \mathrm{ha}^{-1}$ ) on the Organic composition of the seed of winter rape in AL-Azafrinih station (2017-2018)

\section{Conclusions}

Brassica napus L. (canola) responded positively with increasing level Foliar Fe fertilization (Nano-FelO kg. ha-1) and ground fertilizers (N $100 \mathrm{~kg}$. ha-1, P 250 kg. ha-1). Crop growth and yield significantly affected by higher amounts of applied fertilizers. Seed quality aspects, i.e. protein content and oil content represented the variable response to each increment in Foliar Fe fertilization (Nano-Fe10 kg. ha-1).

\section{References}

1. Bakhtiari, M., Moaveni, P, and Sani, B., 2015. The effect of iron nanoparticles spraying time and concentration on wheat. Biological Forum an International Journal 7:679-683.

2. Bahrani, A., 2015. Effect of some micro and macronutrients on seed yield and oil content of rapeseed (Brassica Napus L.). International Journal of Chemical, Environmental and Biological Sciences, 3(1), pp.71-74. Bañuelos GS, Bryla DR, Cook CG., 2002. Vegetative production of kenaf and canola under irrigation in central California. Ind Crop Prod. 15:237-245.

3. Brady, N. C. \& Weil, R. R., 2002. The Nature and Properties of Soils 15th end, 375-419.

4. AOAC. Official method of Analysis of the Association of Official Analytical chemists. 15th Ed. Washington.DC,2004. Frink, C. R., Waggoner, P. E., \& Ausubel, J. H.,1999. Nitrogen fertilizer: Ret-

\begin{tabular}{|c|c|c|c|c|c|}
\hline \multirow{4}{*}{ Parameter } & \multicolumn{5}{|c|}{ Foliar Fe fertilization } \\
\hline & \multicolumn{2}{|c|}{$0 \mathrm{~kg} \cdot \mathrm{ha}^{-1}$} & \multicolumn{2}{|c|}{$5 \mathrm{~kg} \cdot \mathrm{ha}^{-1}$} & $10 \mathrm{~kg}$ \\
\hline & \multicolumn{5}{|c|}{ groundfertilizer (N $\left.100 \mathrm{~kg} \cdot \mathrm{ha}^{-1}, \mathrm{P} 250 \mathrm{~kg} \cdot \mathrm{ha}^{-1}\right)$} \\
\hline & $\begin{array}{c}\text { No-Fer } \\
\left(\mathrm{kg} \cdot \mathrm{ha}^{-1}\right)\end{array}$ & Fer. $\left(\mathrm{kg} \cdot \mathrm{ha}^{-1}\right)$ & No-Fer. (kg. ha $\left.{ }^{-1}\right)$ & Fer $\left(\mathrm{kg} \cdot \mathrm{ha}^{-1}\right)$ & No-Fer. $\left(\mathrm{kg} \cdot \mathrm{ha}^{-1}\right)$ \\
\hline & \multicolumn{5}{|c|}{ macro-micro nutrients of soils $\left(\mathrm{mg} \mathrm{kg}^{-1}\right)$} \\
\hline pH & $7.1^{3}$ & $7.3^{3}$ & $6.90^{\circ}$ & $6.71^{\mathrm{c}}$ & $6.91^{\mathrm{b}}$ \\
\hline $\operatorname{Ec}\left(\mathrm{ds}_{\mathrm{s}} \mathrm{m}^{-1}\right)$ & $5.4^{3}$ & $5.5^{3}$ & $5.7^{3}$ & $6.01^{b}$ & $6^{b}$ \\
\hline $\mathbf{N}$ & $0.1^{3}$ & $0.11^{3}$ & $0.11^{3}$ & $0.12^{3}$ & $0.14^{\mathrm{c}}$ \\
\hline $\mathbf{K}$ & $108^{3}$ & $114^{3}$ & $128^{b}$ & $135^{g}$ & $125^{b}$ \\
\hline $\mathrm{Na}$ & 1457.3 & $1390^{b}$ & $1300.7^{6}$ & $1317.3^{c}$ & $1200.3^{d}$ \\
\hline $\mathrm{Ca}$ & $1780^{\mathrm{a}}$ & $1889^{3}$ & $1257^{\circ}$ & $1397^{c}$ & $1260^{\circ}$ \\
\hline Mg & $229.2^{3}$ & $240.2^{b}$ & $320^{c}$ & $399^{\circ}$ & $340^{c}$ \\
\hline $\mathbf{P}$ & 25.5 & 30.01 & 25.4 & 24.95 & 20.22 \\
\hline $\mathbf{S}$ & $2.8^{3}$ & $2.8^{3}$ & $2.9^{3}$ & $3^{b}$ & $3.1^{\circ}$ \\
\hline $\mathrm{Fe}$ & $0.44^{3}$ & $0.68^{b}$ & $0.97^{c}$ & $1.2^{\circ}$ & $1.3^{d}$ \\
\hline Mn & $31.6^{2}$ & $30.7^{3}$ & $59.2^{b}$ & $58.1^{b}$ & $52.1^{c}$ \\
\hline $\mathrm{Cu}$ & $0.70^{3}$ & $0.78^{3}$ & $0.88^{\circ}$ & $1.17^{c}$ & $0.86^{\circ}$ \\
\hline
\end{tabular}

Table 3: The effect of foliar Nano-Fe fertilization and ground fertilizer ( $N 100 \mathrm{~kg}$. ha- ${ }^{-1}, \mathrm{P} 250 \mathrm{~kg}$. ha-1) on the nutrient content of soil of winter rape in AL-Azafrinih station (2017-2018) 
rospect and prospect. Proceedings of the National Academy of Sciences, 96, 1175-1180.

5. Fanaei, H.R.; M. Galavi.; M. Kafi; and Ghanbari Bonjour., 2009. Amelioration of water stress by potassium fertilizer in two oilseed species. Inc. of plant production 3(2) April:41-54.

6. Kacar, B. \& Katkat, A.V., 1999. Gübreler ve Gübreleme Tekniği. Uludağ Üniversitesi Güçlendirme Vakfı Yayın No:144, Vipaş Yayın No: 20, Bursa.

7. Keikha, G., Fanaei, H., Pol Shekan, M., Akbari-Moghaddam, A and Saravani, F., 2005. The effect of foliar application of Zn, B, and Fe on yield and quality of canola. In: The Proceedings of the 9th Iranian Conference on Soil Science, 2005, Tehran, Iran, 149-153.

8. Mazaherinia, S., Astaraei, A., Fotovvat, A and Monshi, A., 2010 The comparison of iron absorption and accumulation in wheat by the application of natural iron oxides and nano-oxides along with compost and granulated sulfur. Iranian Journal of Agronomy 92:103-111.

9. Naderi, M., Danesh-Shahraki, A.A and Naderi, R., 2011. Application of nanotechnology in the optimization of the formulation of chemical fertilizers. Iranian Journal of Nanotechnology 12:16-23.

10. Orlovius, K., 2003. Oilseed rape. In: Kirbky, E. A. (Ed.). Fertilizing for High Yield and Quality, IPI Bulletin, Basel, 16, 125pp.

11. Page AL, Miller RH, Kenney DR. Method of Soil Analysis, 2nd (ed) Agron. 9. Publisher, Madiason, Wisconsin, 1982.

12. Patil, B. N., Lakkineni, K. C., \& Bhargava, S. C., 1996. Seed yield and yield contributing characters as influenced by $\mathrm{N}$ supply in rapeseed-mustared. Journal of Agronomy and Crop Science, 177, 197-205.

13. Rashno, M.H., Tahmasebi-Sarvestani, Z.A., Heidari Sharifabad, H., Modarres Sanavi, S.A.M and Tavakkol Afshari, R., 2013. The effect of drought stress and iron spraying on yield and quality of two alfalfa cultivars. Iranian Journal of Crop Plants Production 1: 125-148.

14. Rais, L., Masood, A., Inam, A., Khan, N., 2013. Sulfur and Nitrogen Co-ordinately ImprovePhotosynthetic Efficiency, Growth and Proline Accumulation in Two Cultivars of Mustard Under Salt Stress. J Plant Biochem Physio, 1: 101.
15. Rathke G, Christen WO, Diepenbrock W., 2005. Effect of nitrogen source and rate on productivity and quality of winter oilseed rape (Brassica napus L.) grown in different crop rotation. Field Crop Res. 94:103-113.

16. Rensing, L., \& Cornelius, G., 1980. Biological membranes as components of oscillating systems. Biologische Rundschau, 18, 197-209.

17. Sarkar D., Mandal, B. and Kundu, M.C., 2007. "Increasing use efficiency ofboron fertilizers by rescheduling the time and methods of application forcrops in India," Plant Soil. 301: 77-85.

18. SAS Institute Inc. SAS/STAT User's guide. Version 8.SAS Institute, Cary, North Carolina, USA, 1999.

19. Sun, B., Jing, Y., Chen, K., Song, L., Chen, F and Zhang, L., 2007. Protective effect of nitric oxide on iron deficiency induced oxidative stress in maize (Zea mays). Journal Plant Physiology 164:536-543.

20.Singh, S., 2001. Effect of Zn, Fe, on growth on sun flowers. Environmental 34:57-63.

21. Taiz, L., \& Zeiger, E., 1991. Plant physiology: Mineral nutrition (pp. 100-119). Redwood City, CA: The Benjamin Cummings Publishing.

22. Virender, S., M.S. Sidhu, and Y. Sordana., 1994. Effect of integrated nutrient management on thequality and oil yield on Indian rape and Sweden rape intercropping system. Crop Res. Hisar. 8(3): 431-436.

23. Wang, S.H., Yang, Z.M., Yang, H., Lu, B., Li, S.Q and Lu, Y.P., 2004. Copper induced stress and anti-oxidative responses in roots of Brassica juncea. Botanical Bulleting Academia Sinica 45:203-212.

24. Wiersma, J.V., 2005. High rates of Fe-EDDHA and seed iron concentration suggest partial solution to iron deficiency in soybean. Agronomy Journal 97:924-934.

Received: 30 December 2018

Approved: 20 February 2019 